\title{
A NEWLY REVAMPED FRESHMAN ENGINEERING COURSE
}

\author{
Severino L. Koh(1), H. Semih Oktay(2), and Jay Freyman(3) \\ (1) Professor, Department of Mechanical Engineering, UMBC \\ (2) Adjunct Assistant Professor, Department of Mechanical Engineering, UMBC \\ (3) Associate Professor of Ancient Studies and Director of the Honors College \\ UMBC, Baltimore, Maryland 21228-5398, U. S. A.
}

\begin{abstract}
To invigorate an outdated freshman engineering course, and to re-orient this course to fit more effectively into a design-oriented engineering curriculum, a new course was introduced at UMBC.

The main focus of the course was an introduction to engineering design with lectures on selected topics of analysis, computing skills and engineering drafting needed for the design. Analytical results and basic equations were introduced in the course at appropriate times as the design project progressed.

Experience with small "Honors College" classes exceeded all expectations. Students were able to learn the skills needed for a complete teamdesign of a project from the conceptual identification of the design problem to the fabrication and evaluation of a prototype. The larger, general classes were also able to achieve their more limited design goal without the construction of a prototype.
\end{abstract}

\section{INTRODUCTION}

The first engineering course that the incoming freshman encounters in college is traditionally a course that includes an introduction to engineering graphics, the elements of a computer language, and special lectures on the practice of engineering. As in many engineering schools, this course is taught at UMBC as part of the common first-year program that all engineering students take regardless of the specific engineering area that they may choose to pursue.

The importance of this course in the retention of qualified students in the program and in their continued interest and enthusiasm for engineering cannot be overstated. However, over the years, this course has become outdated, lacking in challenge, and can be quite uninteresting and irrelevant.

To remedy the situation, following the lead of its sister-institution UMCP at College Park, UMBC developed an entirely new course for freshman engineering students. The UMBC experimentation is briefly discussed here.

\section{ENGINEERING DESIGN FOR FRESHMAN}

The newly developed design-focused course was first taught at UMBC in the Fall of 1994 with a small class of "Honors College" students. The principal assignment for the class was to design a low-cost, portable shelter for the homeless. Divided into three teams, the class worked as three "companies", each designing the "product" of the company, making all the necessary analysis and calculations and mechanical drawings, selecting the specific materials, asembling the product, testing and evaluating it to determine conformity with specifications. Each "company" wrote a complete technical report and made oral presentations of its project, displying finished prototypes.

In the Fall 1995 semester the new course was offered to the entire freshman engineering class of 130 students, which was divided into four regular sections and a separate class of honor students. A common design project was assigned to the entire class. Where the project of 1994 tried to address a socio-economic problem prevalent in big cities in the United States, the project of 1995 was to demonstrate the breadth of application of engineering: Engineering for the Arts: Design for UMBC's mobile theatre, 


\section{"Shakespeare on Wheels."}

The main assignment was to redesign the transportable flatbed on which the stage is assembled. The class considered different mechanisms to raise and lower the sides of the transporting flatbed as well as to assemble the superstructures for the stage, taking into consideration all factors of good engineering practice and design, for ease of transport, assembly and reassembly for transport to different sites of performance. All teams carried through the design assignment to the completion of reports and oral presentations. Due to resource limitataions, it was only the honors section that was given the additional task of building and evaluating its prototype.

\section{REQUIRED SUPPLEMENTARY SKILLS}

The centerpiece of the course was an introduction to engineering design, but the over-riding unstated goal was to develop in the student the engineering psyche, the engineering mind, the engineer's method of rationalization. Equally important, the design project also provided the justification and motivation for learning basic concepts of engineering, the elements of computation and communication skills. As the design project progressed, lectures on selected topics of engineering concepts, e.g. mechanics, etc., were pres- ented as appropriate. Skills in computation were enhanced as selected software were learned and applied.

\section{CONCLUDING REMARKS}

Expermentation with the new course proved that the lofty goals of a full freshman engineering design course are achievable for small classes of honor students with sufficient support. The limited objective (no workable prototype required) for the large classes is also achievable, although it is recognized that the construction and evaluation of design prototypes would have greatly enhanced the value of the course.

Finally, this new course fits well into the engineering curriculum as the first of a series of design courses that runs through the program.

\section{ACKNOWLEDGEMENTS}

The authors gratefully acknowledge the assistance given by Dr. Rick REYNOLDS, Mr. Brian TIPPETT and $\mathrm{Mr}$. Nitin SALUNKE in the teaching of the experimental classes.

(平成 8 年 4 月 25 日 東南アジア太平洋地域工学教育国 際会議加転載)

\section{Pl8880工学・工業教育関連行事の お知らせ}

\section{第 3 回「工学教育」連合講演会の開催}

日工教主催の「工学教育の国際化々評洒認定制度一大 学と企業の教育の方向性一」をテーマとした標記講演会 が下記のとおり開催される。プログラムの詳細は 3 月号 に会告として掲載する予定であり，多数の御参加を打願 いします。
日 時: 平成 9 年 5 月 16 日(金) $9: 50 \sim 17: 00$
場所：优土木学会図書館講堂 東京都新宿区四谷 1 丁目無番地
主催：陠日本工学教育協会
共催：土木学会 (幹事) 他19学会
後 援：文部省他

プログラム：基調講演 1 件および一般講演 5 件

参 加 費：主催学協会会員 5,000円 その他 7,000円

\section{1st ASIA-PACIFIC FORUM ON ENGINEERING AND EDUCATION}

日 時：1997年7月 6 日(日) 9 日(水)

場所：モナシュ大学 (メルボルン,オーストラリア)

主＼cjkstart催：ユネスコ

論文締切：1997年 3 月 7 日

問 合 先：(社日本工学教育協会（担当：原田）

Tel : 03-5442-1021

Fax : 03-5442-0241

E-mail : jsee@mxk. meshnet.or.jp 